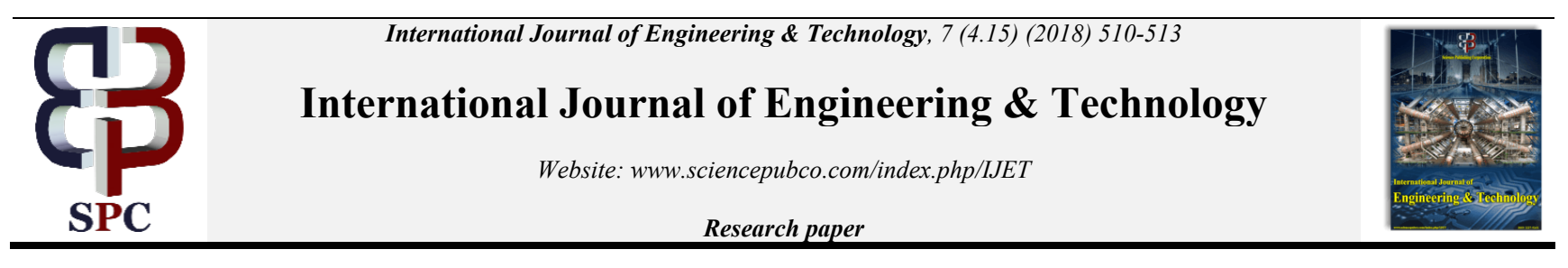

\title{
Exploring the Challenges of Goods and Services Tax on Batik Manufacturers
}

\author{
Zalilawati Yaacob, Nadiah Abd Hamid, nor Fara Shahirah Kamal, Noorlaila Ghazali and Roszilah \\ Shamsuddin
}

Faculty of Accountancy, Universiti Teknologi MARA Puncak Alam Campus, Bandar Puncak Alam, Selangor, Malaysia

\begin{abstract}
The implementation of Goods and Services Tax (GST) in Malaysia has received criticism from various parties such as businesses, policy makers, professionals, business associations and individuals. Despite the rejections from these parties, the government proceeded to implement GST on 1 April 2015. Subsequently, this led to difficulties encountered by businesses, particularly the manufacturing industry in adjusting the production cost, setting prices of products, and comply with the new indirect tax structure. Hence, this study aims to explore the challenges of GST on SME batik manufacturers pertaining to business performance and compliance. A semi structured interviews were conducted on the top management and owners of SME batik manufacturer in two states of Malaysian Peninsular, namely Kelantan and Terengganu. The respondents reported that, during the era of GST, sales of their batik products decreased tremendously. In addition, they described the GST system as a complex system that affects compliance. This study solicits government's attention on the impact of GST on Malaysian batik manufacturers. The findings suggest that it is essential for government to devise plans in reducing the financial burden of batik manufacturers and to simplify the GST mechanism in encouraging a high level of GST compliance.
\end{abstract}

Keywords: GST, Business Performance, Compliance, Batik Industry, Batik Manufacturers, SME, Malaysia

\section{Introduction}

Malaysian government expanded its tax base via the implementation of the Goods and Services Tax (GST) on 1 April 2015. GST is an indirect tax imposed at every production and distribution stage in the supply chain of goods and services made in Malaysia as well as imports to Malaysia. The main reason given by advocates of GST is, it would enhance to mobilize much- needed tax revenue and improve the efficiency of the overall tax system (Keen \& Lockwood, 2010). Similarly, Palil and Ibrahim (2011) accentuated that GST assists government in generating additional revenue offsetting a budget deficit. Despite of the prescribed benefits, the implementation of GST was put on hold since 1989 , as public is not ready to accept a new tax reformation.

Under the GST system, businesses with annual sales turnover above RM500, 000 are required to register with Royal Malaysian Customs Department (RMCD) and are authorised to levy GST which is then refunded. However, businesses with annual sales turnover below the threshold may voluntarily register with RMCD but are not allowed to levy GST. Once registered with RMCD, all businesses transactions must be recorded using GST software by trained employees (Chen \& Taib, 2017). Relatively, GST changes the processes of business transactions, specifically the accounting system, shifting from the manual system to the application software system (Khoo, 2015).

With the implementation of GST, businesses have to bear the burden of high compliance cost, predominantly related to GST training, record keeping, filing GST returns, remitting GST payable as well as claiming input tax refunds (Chen \& Taib, 2017). Accordingly, GST adds complexity in recording businesses transactions, particularly for businesses with manual accounting.

\section{Background of the Study}

Within Malaysian business communities, the Small and Medium Enterprises (SMEs) are manifested as the spine of the industrial development. Specifically, because SMEs are Malaysian largest business establishment, with a Gross Domestic Product (GDP) growth of $5.2 \%$ and contributes to $36.6 \%$ of Malaysian GDP (SMEAnnual Report, 2016/2017). SMEs are also traders for Multi- National Companies in the world-wide chain businesses(Musa \& Chinniah, 2016). The Malaysian SMEs are classified into two categories; (i) manufacturing sectors- with an annual sales turnover of RM50 million or less and full-time employees not exceeding 200 workers, whilst (ii) services sectors - with annual sales turnover not exceeding RM20 million and full-time employees not exceeding 75 workers (SMECorp, 2015). SMEs are highly concentrated in the services sector, which accounted for $94.7 \%$ (859,367 firms), whilst about $5.3 \%$ of SMEs $(47,698)$ are in the manufacturing sector.

Batik industry is an example of a manufacturing sector that form part of the wider textile industry in Malaysia. Batil industry not attracts an outstanding domestic market but international market as well (Ismail, Mokhtar, \& Ali, 2013). 
The value of exported batik products is projected to increase from RM13.4 billion in 2010 to RM24 billion in 2020 (Nair, 2014). Despite of an outstanding projected value, batik industry's ability to reach its full potential in generating an excellent revenue is uncertain due to the domination of microenterprises batik manufacturers (Hairuddin, Noor, \& Ab Malik, 2012).

Batik manufacturers' ability to achieved a notable income is abstruse due to its labour intensive methods of hand drawing or block printing in ensuring the exclusivity of batik products. Such methods distort the adoption of modern technologies and heavy machineries in mass production. In addition, with GST in place, batik manufacturers will be charged GST on the purchase of taxable supplies such as cotton, silk and wax. This affect the production cost and eventually the sales of batik products.

A large body of literatures have examined the effect of GST implementation (Chen and Taib (2017)), (Asmuni, Yusoff, \& Ses, 2017), (Bidin \& Marimuthu, 2016), (Mahd Rizal Palil \& Ibrahim, 2011; Mohd Rizal Palil, Ramli, Mustapha, \& Hassan, 2013). Findings of these studies indicate that the level of acceptance and awareness on GST is moderate, however businesses are facing challenges in understanding the GST mechanism perticulary identifying the input and output tax, which affects their compliance towards the Act.

Based on previous researchers' findings, this study was performed aimed on exploring SME batik manufacturers' experiences during GST era in the context of business performance and GST compliance. In order to achieve the aim, interviews were conducted involving five batik manufacturers from two states in the east coast of Malaysian Peninsular, namely Kelantan and Terengganu. The nature of this study is significant as it solicits government's attention on factors that affect tax reform policy (GST), notably business performance and compliance.

\section{Literature Review}

\subsection{Batik Industry in Malaysia}

Batik is manufactured in a form of decorative cultural artefacts that engaged the artistic work of batik artist utilising stamped candle technique dipped with attractive colours (Hairuddin et al., 2012). Historically, the development of batik in Malaysia started during the Common Era on the $15^{\text {th }}$ century (IKN, 2009), evolved from task inherited by generations of batik maker families in Terengganu and Kelantan; both states are known as the birthplace of Malaysian batik (Hairuddin et al., 2012). Batik industry has been recognised by the United Nation Conference on Trade and Development (UNCTAD) on its capabilities in providing opportunities for economic growth in developing countries such as in Malaysia (Akhir, Ismail, \& Said, 2015). Batik industry is registered under the Malaysian Handicraft with a population of more than 320 businesses (Nordin \& Bakar, 2012).

Batik is widely used as a design in the textile industry (Ismail et al., 2013). The modern way of batik making that began with the canting method and then the printing block method enabled batik manufacturers to produce it on semiindustrial basis (Redzuan \& Aref, 2009) with more appealing designs are being produced.

The popularity of batik fabrics has risen due to high demand from locals as well as tourists. With diversity of products and strategic planning, batik manufacturing industry has the potential to generate a high return through export activities (Akhir et al., 2015).

\subsection{Business Performance}

Businesses all over the world are valued based on their performances, which are considered as the strategic outcomes of firms in measuring their achievement towards their goal and simultaneously act as market-based indicators (Eniola \& Entebang, 2015; Sefiani, 2013). Performance is imperative in managing firms' operations as public valued businesses' potential through it. Various methods may be employed to determine the performance in businesses, particularly the SMEs for instance through financial or organizational effectiveness or both (Eniola \& Entebang, 2015) Generally, businesses use financial performance which measures the difference between income and expenses of the business

Consumers are willing to accept GST (S. Ling, Osman, Arman Hadi, Muhammad Safizal, \& Rana, 2016), however, it does not correlate with the amount they spend on the consumption of goods and services. This is because their disposable income is getting smaller due to the burden of income tax and GST which predominantly affects the middle income group, since they consume most of the taxable items. The long term effect of GST can be demonstrated by the increasing prices of goods and services that lead to the decrease of purchasing power (Mat Nor, Azman, \& Rafdi, 2015) which eventually affect the financial performance of businesses.

\section{3 .Gst Compliance}

GST compliance can be described as the willingness of the tax payer to follow the rules and regulation regarding on GST matter (S. C. Ling, Osman, Muhammad, Yeng, \& Jin, 2016). As proposed by KPMG in their compliance programs (Menon, 2017) GST compliance can be achieved in four steps, involving data import for outward and inward supply along with vendor master and tax ledger; the validation process based on GST tax invoice and regulations; reconciliation and preparation of data sorting; and finally compliance tracking. One of the challenges faced by SMEs on GST implementation is compliance cost. In fact, compliance cost plays a big role in determining the success of a new tax reformation. Compliance cost can be defined as "costs which are incurred by taxpayers [and] or by third parties in meeting the requirements of the tax system, over and above the tax liabilities itself and over and above any harmful distortions of consumption or production to which the tax may give rise" (Sandford, 1981). Relatively, Ramli, Palil, Hassan, and Mustapha (2015) claimed that,with GST, every SME is expected to incur an average compliance costs more than RM28,000 annually.

\section{Research Methodology}

In exploring the challenges of GST on SME batik manufacturers, the data were collected using semi structured interviews conducted on five batik manufacturing businesses located in Kelantan and Terengganu which w e $r$ e chosen because majority population of batik manufacturers reside in both states. The sample population of this study is based on the number of SMEs in batik industry gathered from the directories of Perbadanan Kemajuan Kraftangan Malaysia (PKKM) Terengganu and Kelantan. The respondents of this study are the business owners and the management of batik manufacturers with GST knowledge and experience.

A semi structured interviews were used, to allow a series of 
questions without restriction on fixed order, presented together with additional questions that fits the context of this study. The interviews were conducted in "Bahasa Malaysia" respecting the preference of the respondents. On $18^{\text {th }}$ and 19th January 2017 between 9.00 a.m. to 4.30 p.m. respondents from Kuala Terengganu were interviewed at their premises. While, the respondents from Kelantan were interviewed via telephone from 22 January until 26 January 2017 which starts at 10.30 a.m. Each interview took an average time of half an hour. The profile of the interviewees is presented in Table 1.

Table 1: Profile of the Interviewees

\begin{tabular}{|l|l|l|l|l|}
\hline Co. & States & Position & Education & $\begin{array}{l}\text { Work } \\
\text { Experience }\end{array}$ \\
\hline A & Terengganu & Manager & Degree & 5 years \\
\hline B & Terengganu & Owner & Master & 15 years \\
\hline C & Kelantan & Owner & SPM & 35 years \\
\hline F & Terengganu & Accountant & Degree & 2 years \\
\hline H & Kelantan & Owner & SPM & 20 years \\
\hline
\end{tabular}

\section{Results and Discussion}

\subsection{GST Effect on Business Performance}

The sales of batik products dropped significantly during the early stage of GST implementation. Interviewees perceived that GST is a burden, as they have to increase the price of their products, particularly the batik textiles as a result of a significance increase in the cost of imported raw materials such as cotton, silk, wax and dye.

Two interviewees commented: Manager of Company A: "The increasing cost of raw material led me to increase my product price. Based on my monthly report, sales on first quarter of 2015 which (January until March) was the highest in year 2015. The period between April until June 2015 recorded the lowest sales

The owner of Company C:

"Under GST, all raw materials for batik textiles a r e $t$ a $x$ a ble items. This increase $m y$ production costs" The increase in cost of production is worsened due to absorption of the GST as part of their operation cost in maintaining the sales of batik products.

For example the Accountant of Company F noted: "With GST the demand for our products have decreased. Customers are not willing to pay for GST, therefore my company absorb the GST to ensure that customers still purchase from us",

\subsection{GST Compliance}

Even though the business owners and their employees comply with the GST system by attending GST course, yet it does not enhance their understanding.

For example the owner of company B noted:

"Before the GST, all business records focused on the revenue and expenses only, but with GST, all the expenses must be categorized according to the type of expenses or revenues. Recording the transaction, took longer because I am not confident with the treatment of the transaction I am afraid that any mistake in the recording process will lead to penalty by Royal Malaysian Custom Department (RMCD)'”.

The accountant of Company $\mathrm{F}$ explains that:

"I need to order new invoices as government requires all GST invoices to be printed. Then, I need to ensure that there is no error in claiming the input tax from RMCD. For the first three months after GST being implemented, I faced problems on items that are claimable not claimable for GST. The procedures to submit the GST-03 form seems to be difficult to follow".

The owner of Company $\mathrm{H}$ explains that:

"The procedure on GST seems to be complicated since it has many procedures to be followed. If the government or RMCD can make the procedure much simpler and easy to follow, businesses will not be burden with compliance. I belief it may encouraged business owners to voluntary comply with the law"

The manager of Company A noted:

"My company is GST registrant, I purchased a new computer software, and send my employee for training and workshop related to GST".

The delivery on GST information was not properly executed by RMCD branch officers. This cause difficulty among the business owners in understanding the application of GST system particularly in relation toinput and output tax.

The manager of Company A commented

"At the early stage of implementation of GST, it took a lot of my time, especially when dealing with Royal Malaysian Custom Department (RMCD) officer. I need to call them many times regarding to input tax and output tax since these terms are new to me. Unfortunately, most of the RMCD whom are in charge with GST does not really understand the application of GST on batik manufacturing process. Some of the RMCD officers asked me to call the officers in Kuala Lumpur. The government should ensure that RMCD officers possess clear understanding on GST and able to help the taxpayers".

\section{Conclusion}

GST broadens the tax base as it brings many of the entrepreneurs and taxpayers whom are not paying taxes under the tax net. However, the impact of such indirect tax towards SME batik manufacturers is considered as quite substantial, as all the non-exempt business transactions are captured in the GST regime, that cause an effect on additional tax.

The RMCD plays an important role in delivering the necessary support and training on GST. However, some of RMCD's branch officers fail to do so. Data form this study suggest that it is essential for government to provide incentives to reduce the financial bu rden of batik manufacturers, create awareness and educate them on GST mechanism and simplify the GST system in encouraging high rate of GST compliance.

\section{Acknowledgement}

The authors would like to express their gratitude to Universiti Teknologi MARA for granting LESTARI grant ref no: 600IRMI/MyRA5/3/LESTARI (033/2017). Special thanks also goes to the Faculty of Accountancy and Research Management Centre (RMC) of Universiti Teknologi MARA for their trust and continuous support.

\section{References}

[1] Akhir, N. H. M., Ismail, N. W., \& Said, R. (2015). Traditional Craftsmanship: The Origin, Culture, and Challenges of Batik Industry in Malaysia Islamic perspectives relating to business, arts, culture and communication

[2] (pp. 229-237): Springer.

[3] Asmuni, S., Yusoff, S., \& Ses, N. S. M. (2017). Acceptance towards Goods and Services Tax (GST) among local business 
communities.

[4] Journal of Emerging Economies \& Islamic Research, 5.

[5] Bidin, Z., \& Marimuthu, M. (2016). Attitude determinants in proposed goods and services tax among manufacturing companies in Malaysia. International Review of Management and Marketing, 6(8S).

[6] Chen, L. E., \& Taib, M. S. B. M. (2017). Goods and Services Tax (GST): Challenges Faced by Business Operators in Malaysia. Paper presented at the SHS Web of Conferences.

[7] Eniola, A. A., \& Entebang, H. (2015). Government policy and performance of small and medium business management.

[8] International Journal of Academic Research in Business and Social Sciences, 5(2), 237

[9] Hairuddin, H., Noor, N. L. M., \& Ab Malik, A.

[10] M. (2012). Why do microenterprise refuse to use information technology: A case of batik microenterprises in Malaysia. Procedia-Social and Behavioral Sciences, 57, 494-502.

[11] IKN. (2009). Seni Kraf Batik: Motif \& Teknik. Ismail, W. N., Mokhtar, M. Z., \& Ali, A. (2013). Design activities and the difference level of sales and profits performance of the batik

[12] SMEs in Malaysia. International Review of Management and Business Research, 2(2), 627-642.

[13] Keen, M., \& Lockwood, B. (2010). The value added tax: Its causes and consequences.

[14] Journal of Development Economics, 92(2), 138-151.

[15] Khoo, S. (2015, 30 Mar 2015). Challenges of GST: Cost management and competitiveness,

[16] The Star Online. Retrieved from

[17] https://www.thestar.com.my/tech/technews/2015/03/30/challeng es-of-gst-cost-management-and-competitiveness/

[18] Ling, S., Osman, A., Arman Hadi, A.,Muhammad Safizal, A., \& Rana, S. (2016). Public acceptance and compliance on Goods and Services Tax (GST) implementation: A case study of Malaysia. Asian J. of Soc. Sc. \& Hum, 5(1), 1-12.

[19] Ling, S. C., Osman, A., Muhammad, S., Yeng, S. K., \& Jin, L. Y. (2016). Goods and Services Tax (GST) compliance among Malaysian

[20] consumers: The influence of price, government subsidies and income inequality. Procedia Economics and Finance, 35, 198-205. Mat Nor, F., Azman, A. S., \& Rafdi, N. (2015). Kesan Perlaksanaan GST: Keperluan Penetapan Semula Had Kifayah. Paper presented at the International Conference on Management and Muamalah.

[21] Menon, S. (2017). KPMG Compliance Pilot. Musa, H., \& Chinniah, M. (2016). Malaysian SMEs Development: Future and Challenges on Going Green. Procedia-Social and Behavioral Sciences, 224, 254-262.

[22] Nair, N. (2014). A boost for batik, The Star Online. Retrieved from

[23] https://www.thestar.com.my/news/community/2014/09/26/aboost-for-batik- designers-work-lifts-profile-of-traditionalfabric/

[24] Nordin, R., \& Bakar, S. S. A. (2012). Malaysian Batik Industry: Protecting Local Batik Design by Copyright and Industrial Design Laws.

[25] International Journal of Business and Society, 13(2), 117. Palil, M. R., \& Ibrahim, M. (2011). The impacts of goods and services tax (GST) on middle income earners inMalaysia. World Review of Business Research, 1(3), 192 206.

[26] Palil, M. R., Ramli, R., Mustapha, A. F., \& Hassan, N. S. A. (2013). Elements of compliance costs: Lesson from Malaysian companies towards Goods and Services Tax (GST). Asian Social Science, 9(11), 135.

[27] Ramli, R., Palil, M. R., Hassan, N. S. A., \& Mustapha, A. F. (2015). Compliance costs of Goods and Services Tax

[28] (GST) among small and medium enterprises. Jurnal Pengurusan (UKM Journal of Management), 45.

[29] Redzuan, M. r., \& Aref, F. (2009). Path-analysis model of the development of handicraft (batik) industries in kelantan, Malaysia. Journal of American Science, 5(8)

[30] 31-38

[31] Sandford, C. (1981). Costs and benefits of VAT: William Heinemann Limited.

[32] Sefiani, Y. (2013). Factors for success in SMEs: perspective from Tangier. University of Gloucestershire.

[33] SMEAnnual Report. (2016/2017). from

[34] http://www.smecorp.gov.my/images/SMEAR/latest/Chapter2.pdf

[35] SMECorp. (2015). from

[36] http://www.smecorp.gov.my/index.php/en/policies/2015-12-2109-09-49/sme-definition?id=371 